\title{
Modulatory effect of protocatechuic acid on cadmium induced nephrotoxicity and hepatoxicity in rats in vivo
}

\author{
Stephen A. Adefegha, Olasunkanmi S. Omojokun * and Ganiyu Oboh
}

\begin{abstract}
Introduction: This study sought to investigate the effect of protocatechuic acid (PCA); a phenolic compound readily available in most plant foods on cadmium-induced nephrotoxicity and hepatoxicity in rats.

Case description: Thirty six adult male rats weighing about 150-160 g were acclimatized for 2 weeks and subsequently divided into six groups: Group 1 rats received normal saline (control group), group 2 rats were administered $5 \mathrm{mg} \mathrm{Cd} / \mathrm{kg}$ body weight in form of solution orally (induced group), groups 3 and 4 received cadmium solution and different doses of PCA (10 and $20 \mathrm{mg} / \mathrm{kg}$ body weight) respectively, while groups 5 and 6 were the normal rats administered different doses of PCA (10 and $20 \mathrm{mg} / \mathrm{kg}$ ) respectively in an experiment that lasted for twenty one days. The animals were sacrificed, the blood was collected and the serum was subsequently prepared. Furthermore, the liver was excised, homogenized and centrifuged to obtain the tissue homogenate used for the analyses. The serum was used for the determination of the total protein, urea, creatinine and uric acid levels while the liver homogenate was used for the estimation of alanine aminotransferase (ALT), aspartate transaminase (AST), and alkaline phosphatase (ALP).
\end{abstract}

Discussion and evaluation: The result revealed that total protein level was reduced in cadmium induced toxicity rat group which was elevated upon treatment with PCA. Conversely, the elevated levels of urea, uric acid and creatinine in cadmium induced toxicity kidney rats were significantly $(p<0.05)$ reduced in PCA treated groups. Similarly, marked elevation in the ALT, AST and ALP activity were observed in cadmium induced toxicity rat group when compared with the control group. However, significant $(p<0.05)$ decrease in ALT, AST and ALP activity were noticed in groups administered different doses of PCA.

Conclusions: The results from this study suggest that PCA may protect against cadmium-induced toxicity in the kidney and liver.

Keywords: Cadmium, Hepatotoxicity, Nephrotoxicity, Protocatechuic acid

\section{Background}

Cadmium (Cd) is a heavy metal obtained as a by-product of zinc. It is one of the most toxic environmental and industrial pollutants, obtained through consumption of foods and drinking water, inhaled from air or cigarette smoking or from ingestion of contaminated soil and dust. It is a long biological half-life, toxic and

\footnotetext{
*Correspondence: sunjoks@live.com

Functional Foods and Nutraceuticals Unit, Department of Biochemistry, Federal University of Technology, P.M.B. 704, Akure 340001, Ondo State, Nigeria
}

non-biodegradable metal that is non-beneficial to plants, animals and humans (Jarup et al. 2000). The most important target organ for chronic low-level exposure to $\mathrm{Cd}$ is the kidney and is reflected in proteinuria, calciuria, aminoaciduria, glycosuria and tubular necrosis (Satarug et al. 2010) which may eventually lead to end-stage renal failure, deregulated blood pressure, diabetic complications and osteoporosis (Satarug and Moore 2004). In addition, $\mathrm{Cd}$ has the propensity to settle in the proximal tubule of the nephron, leading to nephrotoxicity (Ahn et al. 1999).

\section{Springer}

(C) 2015 Adefegha et al. This article is distributed under the terms of the Creative Commons Attribution 4.0 International License (http://creativecommons.org/licenses/by/4.0/, which permits unrestricted use, distribution, and reproduction in any medium, provided you give appropriate credit to the original author(s) and the source, provide a link to the Creative Commons license, and indicate if changes were made. 
Cd shows different mechanisms of toxicity under different experimental conditions and in various species. When some toxicants enter into the human system they result in disturbance in the redox balance in cells in favour of oxidants, with the imbalance resulting in oxidative stress which eventually results in oxidative damage to the cellular macromolecules and cellular structures (Waisberg et al. 2003). Although, the biochemical mechanism behind $\mathrm{Cd}$ nephrotoxicity and hepatotoxicity is not perfectly understood, once taken up enterally, Cd reaches the liver where it binds to metallothioneins (MTs), glutathione (GSH) and other proteins or peptides (Thevenod 2009). Even though, mitochondria have been identified as the earliest target organelles of Cd-induced nephrotoxicity, antioxidants are known to protect against oxidative stress and Cd-induced nephrotoxicity (Tang and Shaikh 2001).

Protocatechuic acid (PCA) which is chemically known as 3, 4-hydroxybenzoic acid is a widely distributed naturally occurring phenolic acid and also one of the main metabolites of complex polyphenols which are normally found at high concentrations in vegetables and fruit, and are readily absorbed by animals and humans (Vitaglione et al. 2007). Protocatechuic acid has multifaceted biological effects by acting on different molecular targets as it is shown to possesses antioxidant, anti-inflammatory as well as anti-hyperglycemic activities (Lin et al. 2009). However, there are new insights in the comprehension of the cellular and molecular mechanisms responsible for the potential preventive/therapeutic activity of PCA against a number of human diseases, but there is a dearth of information on its nephro-protective and hepato-protective mechanism. Hence we propose in this study to investigate possible modulatory effect of Protocatechuic acid on liver marker enzymes and kidney parameters in cadmium-induced hepatotoxicity and nephrotoxicity in rats in vivo.

\section{Materials and case descriptions Materials}

Kits used for bioassay (total protein, urea, uric acid, creatinine, ALT, AST and ALP) were sourced from Randox Laboratories Ltd., Crumlin, County Antrim, UK. Except where otherwise stated, all chemicals used were sourced from Sigma Co. (St Louis MO, USA). The water used was glass distilled.

\section{Experimental animal and treatment groups}

Thirty six adult male Wistar rats weighing about 150$160 \mathrm{~g}$ were purchased from Central Animal House University of Ibadan, Oyo state. In this work, six groups were taken; each group comprised six male healthy rats. The first group served as control group with a normal feed and normal saline which is used as the positive control group, the induced group (group II) received cadmium chloride only orally (5 $\mathrm{mg}$ of $\mathrm{Cd} / \mathrm{kg}$ of body weight in form of solution) which is the negative control. The third group received cadmium and $10 \mathrm{mg} / \mathrm{kg} \mathrm{PCA}$, the fourth group received cadmium and $20 \mathrm{mg} / \mathrm{kg} \mathrm{PCA}$, the fifth and sixth groups received (10 and $20 \mathrm{mg} / \mathrm{kg}$ body weight) PCA respectively. The rats were selected and kept in controlled conditions of about $12 \mathrm{~h}$ dark and $12 \mathrm{~h}$ light (alternative dark light cycle 12:12). All the animals were fed with a standard laboratory feed and water ad libitum. Care and treatment of the animals were performed accordingly. All the procedure were carried out orally. At the end of the experimental period, the animals were anaesthetized and sacrificed after overnight fast.

\section{Animal ethics}

The male Wistar rats used received humane care according to the criteria outlined in the Guide for the Care and the Use of Laboratory Animals prepared by EU Directive 2010/63/EU for animal experiments. The ethic regulations have been followed in accordance with national and institutional guidelines for the protection of animals' welfare during experiments. The experiment was carried out at the Functional Food, Nutraceuticals and Phytomedicine Laboratory, Department of Biochemistry, Federal University of Technology, Akure, Ondo State, Nigeria.

\section{Homogenate preparation and Serum sample analysis}

The rats were decapitated via cervical dislocation and the liver was rapidly dissected, placed in phosphate buffer $\mathrm{pH} 7.4$ on ice and weighed. This tissue was subsequently rinsed with the phosphate buffer $\mathrm{pH} 7.4$ and later homogenized with the phosphate buffer $\mathrm{pH} 7.4$ (1:5 w/v), with about 10-up and down strokes at approximately 1200 $\mathrm{rev} / \mathrm{min}$ in a Teflon-glass homogenizer. The homogenate was centrifuged for $10 \mathrm{~min}$ at $3000 \mathrm{~g}$ to yield a pellet that was discarded and the supernatant was used for ALT, AST and ALP assay.

Function of kidney was assessed by measuring the concentration of total protein, urea, uric acid and creatinine in serum.

\section{Methods}

\section{Determination of serum total protein concentration}

The total protein concentration was determined using the method described by Lowry et al. $10 \mu \mathrm{l}$ of distilled water was pipetted into the test tube labeled blank, $10 \mu \mathrm{l}$ of standard was added to the test tube labeled standard, and $10 \mu \mathrm{l}$ of the sample was added to the sample test tube. $500 \mu \mathrm{l}$ of Reagent was added to the three test tubes. The solution was mixed and incubated for $30 \mathrm{~min}$ at 
$25^{\circ} \mathrm{C}$ after which absorbance was read at $540 \mathrm{~nm}$ (Lowry et al. 1951).

\section{Determination of serum uric acid concentration}

The uric acid concentration was determined using spectrophotometric method described by Collin and Diehl with slight modification by Morin and Prox. Briefly, $20 \mu \mathrm{L}$ of distilled water was added to $20 \mu \mathrm{L}$ of the sample which was mixed with $1 \mathrm{~mL}$ of Hepes reagent $(50 \mathrm{mM}$ phosphate buffer, $4 \mathrm{mM}$ 3,5-chloro-2-hydroxybenzenesulfonic acid) and enzyme reagent $(0.25 \mathrm{mM} \mathrm{4-ami-}$ nophenazone, peroxidise, and uricase). Thereafter, the mixture was incubated for $5 \mathrm{~min}$ at $37{ }^{\circ} \mathrm{C}$ and the absorbance at $520 \mathrm{~nm}$ was taken against reagent blank within 30 min (Collin and Diehl 1959; Morin and Prox 1973). The uric acid concentration was subsequently calculated against the standard.

\section{Determination of serum urea concentration}

The urea concentration was determined using spectrophotometric method described by Searcy et al. Briefly, $10 \mu \mathrm{L}$ of sample was added to $0.1 \mathrm{~mL}$ of sodium nitroprusside-urease reagent $(116 \mathrm{mM}$ EDTA, $6 \mathrm{mM}$ sodium nitroprusside, $1 \mathrm{~g} / \mathrm{L}$ urease) after which the mixture was incubated for $10 \mathrm{~min}$ at $37{ }^{\circ} \mathrm{C} .2 .5 \mathrm{~mL}$ of $120 \mathrm{mM}$ diluted phenol and $2.5 \mathrm{~mL}$ of $27 \mathrm{mM}$ sodium hypochlorite solution containing $0.14 \mathrm{~N}$ sodium hydroxide which was then added to the reaction mixture. Thereafter, the mixture was incubated for $15 \mathrm{~min}$ at $37^{\circ} \mathrm{C}$ and the absorbance at $546 \mathrm{~nm}$ was taken against reagent blank within $8 \mathrm{~h}$ (Searcy et al. 1967). The urea concentration was subsequently calculated against the standard.

\section{Determination of serum creatinine concentration}

The creatinine concentration was determined using spectrophotometric alkaline Jaffe picrate method as described by Spierto et al. Briefly, $50 \mu \mathrm{L}$ of distilled water was added to $2 \mathrm{~mL}$ of working reagent $(35 \mathrm{mM}$ picric acid and $0.32 \mathrm{M}$ sodium hydroxide) before $50 \mu \mathrm{L}$ of sample was added. Thereafter, the mixture was allowed to stay for $30 \mathrm{~s}$ before taking absorbance. The absorbance at $492 \mathrm{~nm}$ was taken twice, firstly after $30 \mathrm{~s}$ and secondly after 2 min (Spierto et al. 1979). The creatinine concentration was subsequently calculated against the standard, using change in the sample absorbance.

\section{Determination of aspartate transaminase (AST) activity}

This was carried out according to the method of Reitman and Frankel as described by the manufacturer's manual (Randox Laboratories Ltd). Briefly, $100 \mu \mathrm{l}$ of test sample was mixed with $500 \mu \mathrm{l}$ of buffer (containing $100 \mathrm{mM}$ phosphate buffer $\mathrm{pH} 7.4,100 \mathrm{mM}$ L-aspartate, and $2 \mathrm{mM} \alpha$-oxoglutarate) and the mixture was incubated for $30 \mathrm{~min}$ at $37^{\circ} \mathrm{C}$. Thereafter, $500 \mu \mathrm{l}$ of $2 \mathrm{mM} \mathrm{2,4} \mathrm{dini-}$ trophenylhydrazine was added to the reaction mixture and allowed to stand for $20 \mathrm{~min}$ at $25{ }^{\circ} \mathrm{C}$. Then, $500 \mu \mathrm{l}$ of $0.4 \mathrm{mM} \mathrm{NaOH}$ was added and thoroughly mixed; the absorbance was read after $5 \mathrm{~min}$ at $546 \mathrm{~nm}$ against a reagent blank and the AST activity determined (Reitman and Frankel 1957).

\section{Determination of alanine aminotransferase (ALT) activity}

This was carried out according to the method of Reitman and Frankel as described by the manufacturer's manual (Randox Laboratories Ltd). Briefly, $100 \mu \mathrm{l}$ of test sample was mixed with $500 \mu \mathrm{l}$ of buffer (containing $100 \mathrm{mM}$ phosphate buffer $\mathrm{pH} 7.4,200 \mathrm{mM} \mathrm{L}$-alanine and $2 \mathrm{mM} \alpha$-oxoglutarate) and the mixture was incubated for $30 \mathrm{~min}$ at $37^{\circ} \mathrm{C}$. Thereafter, $500 \mu \mathrm{l}$ of $2 \mathrm{mM} \mathrm{2,} 4$ dinitrophenylhydrazine was added to the reaction mixture and allowed to stand for $20 \mathrm{~min}$ at $25{ }^{\circ} \mathrm{C}$. Then, $500 \mu \mathrm{l}$ of $0.4 \mathrm{mM} \mathrm{NaOH}$ was added and thoroughly mixed; the absorbance was read after $5 \mathrm{~min}$ at $546 \mathrm{~nm}$ against a reagent blank and the AST activity determined (Reitman and Frankel 1957).

\section{Determination of alkaline phosphatase activity (ALP)}

The serum ALP concentration was determined using spectrophotometric method according to the recommendations of Deutsche Gesellschaft fur Klinische Chemie,. Briefly, $20 \mu \mathrm{l}$ of the test sample was mixed with $1 \mathrm{ml}$ of reacting mixture (containing $1 \mathrm{M}$ Diethanolamine buffer $\mathrm{pH}$ 9.8, $0.5 \mathrm{mM} \mathrm{MgCl}_{2}$ and $10 \mathrm{mM} p$-nitrophenylphosphate). The absorbance was then read at 1 min interval for $3 \mathrm{~min}$ at $405 \mathrm{~nm}$ and the ALP activity was subsequently determined (DGKC 1972).

\section{Data analysis}

The results of replicate readings were pooled and expressed as mean \pm standard deviation. Unpaired Student's $t$ test was used for analyzing the data between two groups, whereas one-way analysis of variance (ANOVA) followed by multiple comparison tests (Tukey's test) was employed for the post hoc (Zar 1984). GraphPad prism 6 software package for Windows was used for the analysis. The level of significance was accepted at $P<0.05$ for the assessment of in vivo biochemical parameters.

\section{Case presentation}

The effect of protocatechuic acid (PCA) on the protein level in rat serum induced with cadmium $(5 \mathrm{mg}$ of $\mathrm{Cd} /$ $\mathrm{kg} \mathrm{B.W)}$ as shown in Fig. 1 revealed that there was significant $(\mathrm{p}<0.05)$ reduction in protein level of cadmiumtreated rat group when compared with the normal control group. However, co-treatment of cadmium with 10 or $20 \mathrm{mg} / \mathrm{kg}$ PCA significantly $(\mathrm{p}<0.05)$ elevated the 


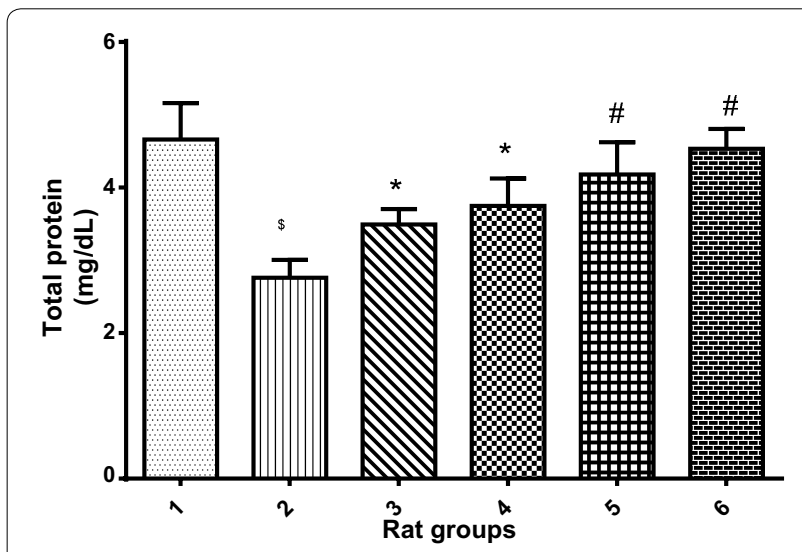

Fig. 1 Effect of protocatechuic acid on total protein concentration in the serum of rats exposed to cadmium. \$Group 2 (Cadmium-induced toxicity) significantly $(p<0.05)$ different from group 1 (normal control). *Group 3 (Cadmium + $10 \mathrm{mg} / \mathrm{kg} \mathrm{B.W} \mathrm{PCA)} \mathrm{and} 4$ (Cadmium +20 mg/kg B.W PCA) significantly $(p<0.05)$ different from group 2 (Cadmium-induced toxicity). "Group 5 (10 mg/kg B.W PCA) and $6(20 \mathrm{mg} / \mathrm{kg}$ B.W PCA) not significantly $(p>0.05)$ different from group 1 (normal control)

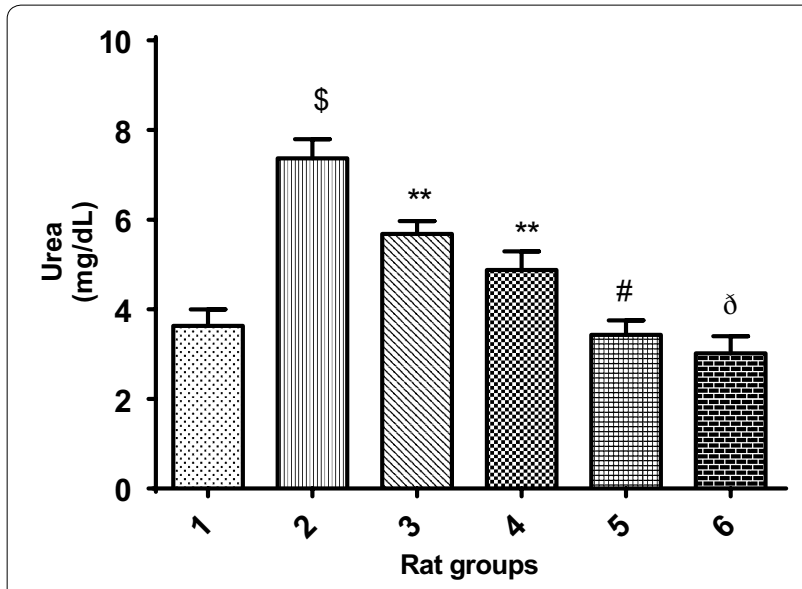

Fig. 2 Effect of protocatechuic acid on urea level in the serum of rats exposed to cadmium. \$Group 2 (Cadmium-induced toxicity) significantly $(p<0.05)$ different from group 1 (normal control). **Group 3 (Cadmium + 10 mg/kg B.W PCA) and 4 (Cadmium + 20 mg/kg B.W $P C A)$ very significantly $(p<0.05)$ different from group 2 (Cadmiuminduced toxicity). "Group 5 (10 mg/kg B.W PCA) not significantly ( $p>0.05$ ) different from group 1 (normal control). ${ }^{\circ}$ Group 6 (20 mg/ kg B.W PCA) significantly ( $p<0.05$ ) different from group 1 (normal control)

protein level. Also, administration of PCA (10 or $20 \mathrm{mg} /$ $\mathrm{kg}$ ) resulted in the elevation of the protein level with no significant $(p>0.05)$ difference when compared with normal control.

Furthermore, Fig. 2 revealed that cadmium administration significantly $(\mathrm{p}<0.05)$ increased the urea level in cadmium-treated rats when compared with the normal control group. However, co-treatment of cadmium with
10 or $20 \mathrm{mg} / \mathrm{kg}$ PCA (Group 3 and 4 respectively) showed obvious significant $(\mathrm{p}>0.05)$ decrease in urea level. In addition, treatment with 10 or $20 \mathrm{mg} / \mathrm{kg}$ PCA (Group 5 and 6 respectively) significantly $(\mathrm{p}<0.05)$ reduced the urea level when compared with cadmium-treated group. Similarly, there was a significant decrease $(\mathrm{p}<0.05)$ in urea level in normal rat treated with PCA (10 and $20 \mathrm{mg} /$ $\mathrm{kg}$ ) when compared with the cadmium-treated group (Fig. 2). Although, the decrease in urea level of the $20 \mathrm{mg} /$ kg PCA group has slight significant $(\mathrm{p}<0.05)$ difference from the normal control group, this could ascertain the $20 \mathrm{mg} / \mathrm{kg}$ as the fixed dose for further biochemical studies. Similarly, Fig. 3 revealed that cadmium administration significantly $(\mathrm{p}<0.05)$ increased the uric acid level in cadmium-treated group when compared with the normal control group. However, co-treatment of cadmium with 10 or $20 \mathrm{mg} / \mathrm{kg}$ PCA showed significant ( $\mathrm{p}>0.05)$ decrease in uric acid level. In addition, there was a significant difference $(\mathrm{p}<0.05)$ in uric acid level in normal rat treated with PCA (10 and $20 \mathrm{mg} / \mathrm{kg}$ ) when compared with the cadmium-treated group as well as with normal control group. Also, Cd administration significantly $(\mathrm{p}<0.05)$ increased the creatinine level in Cd-treated negative control group when compared with the normal control group. However, there was a significant decrease $(\mathrm{p}<0.05)$ in creatinine level of rats in the groups cotreated with cadmium and PCA (10 and $20 \mathrm{mg} / \mathrm{kg}$ ) when compared with the cadmium-induced toxicity group (Fig. 4). Furthermore, no significant ( $\mathrm{p}>0.05$ ) change was observed between the PCA (10 and $20 \mathrm{mg} / \mathrm{kg}$ ) treated and normal control groups.

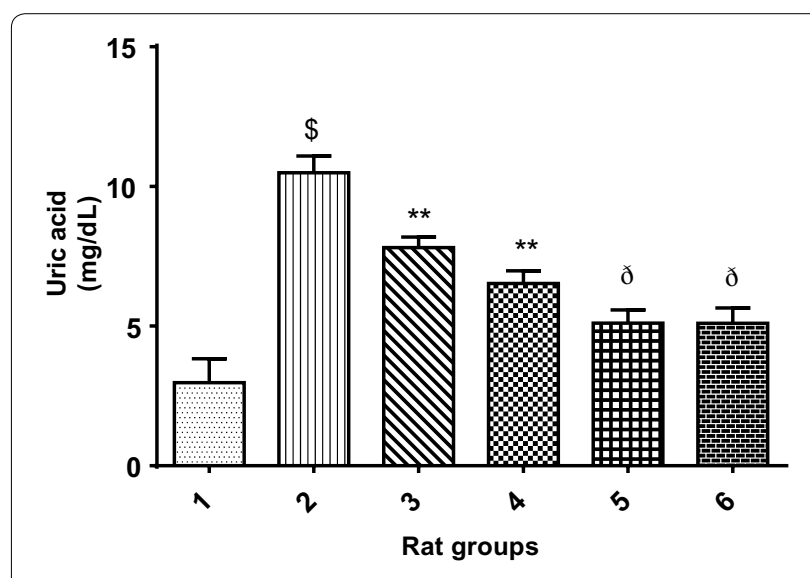

Fig. 3 Effect of protocatechuic acid on uric acid level in the serum of rats exposed to cadmium. ${ }^{\$}$ Group 2 (Cadmium-induced toxicity) significantly $(p<0.05)$ different from group 1 (normal control). **Group 3 (Cadmium $+10 \mathrm{mg} / \mathrm{kg}$ B.W PCA) and 4 (Cadmium $+20 \mathrm{mg} / \mathrm{kg} \mathrm{B.W}$ $P C A)$ very significantly $(\mathrm{p}<0.05)$ different from group 2 (Cadmiuminduced toxicity). ${ }^{\circ}$ Group 5 (10 mg/kg B.W PCA) and 6 (20 mg/kg B.W $P C A)$ significantly $(p<0.05)$ different from group 1 (normal control) 


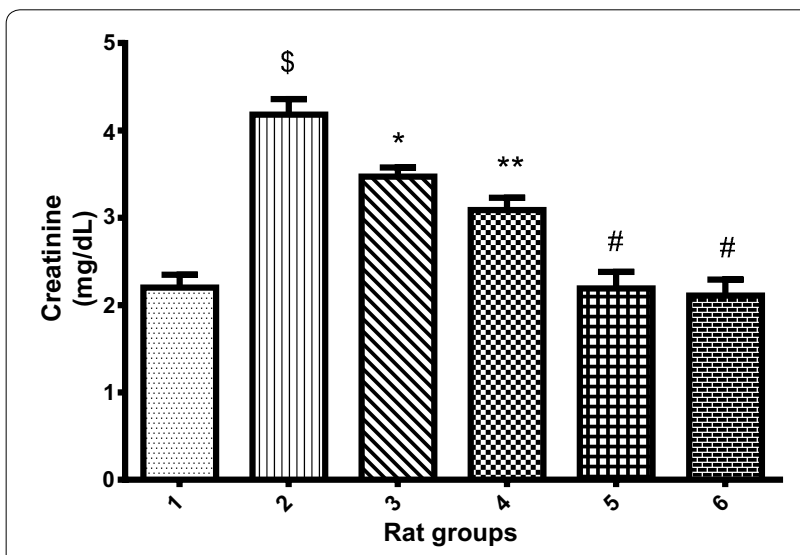

Fig. 4 Effect of protocatechuic acid on creatinine level in the serum of rats exposed to cadmium. \$Group 2 (Cadmium-induced toxicity) significantly $(p<0.05)$ different from group 1 (normal control). *Group 3 (Cadmium + 10 mg/kg B.W PCA) significantly $(p<0.05)$ different from group 2 (Cadmium-induced toxicity). ${ }^{* *}$ Group 4 (Cadmium +20 mg/kg B.W PCA) very significantly $(p<0.05)$ different from group 2 (Cadmium-induced toxicity). "Group 5 (10 mg/kg B.W PCA) and 6 (20 mg/kg B.W PCA) not significantly ( $p>0.05)$ different

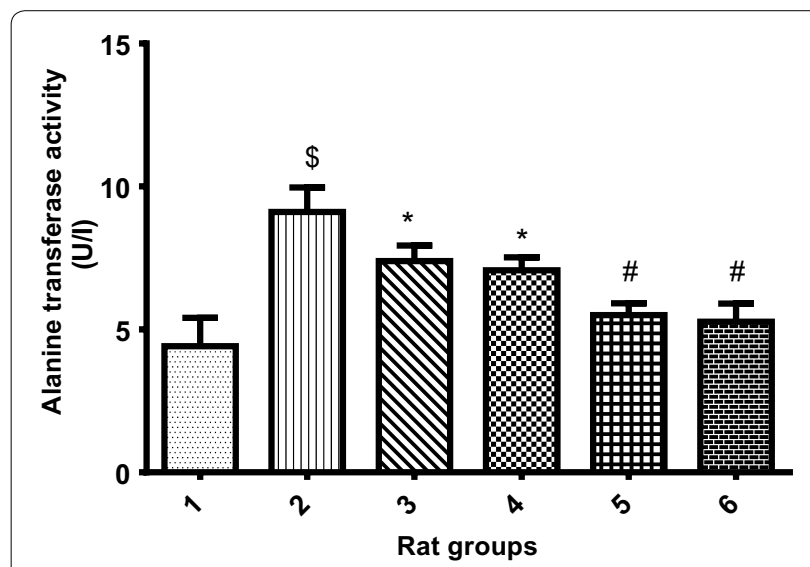

Fig. 5 Effect of protocatechuic acid on ALT activity in the liver of rats exposed to cadmium. ${ }^{\$}$ Group 2 (Cadmium-induced toxicity) significantly $(p<0.05)$ different from group 1 (normal control). *Group 3 (Cadmium + $10 \mathrm{mg} / \mathrm{kg}$ B.W PCA) and 4 (Cadmium + $20 \mathrm{mg} / \mathrm{kg}$ B.W PCA) significantly ( $p<0.05$ ) different from group 2 (Cadmiuminduced toxicity). "Group 5 (10 mg/kg B.W PCA) and 6 (20 mg/kg B.W PCA) not significantly ( $p>0.05$ ) different from group 1 (normal control) from group 1 (normal control)

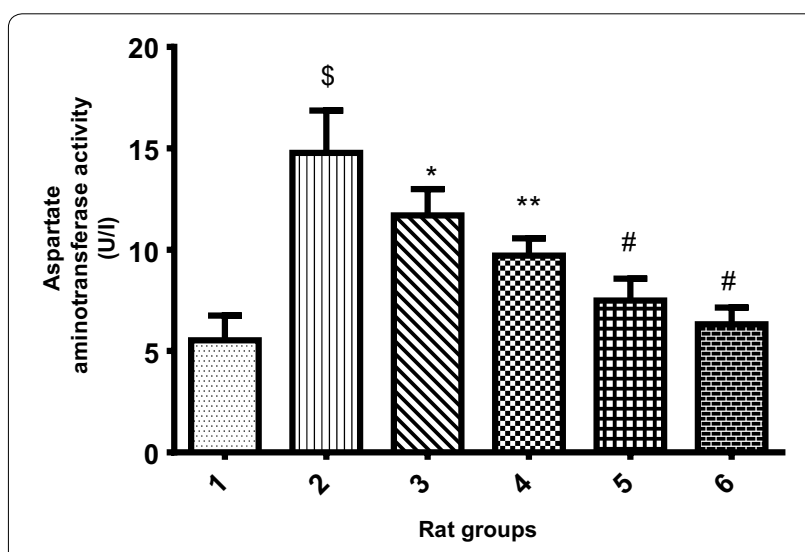

Fig. 6 Effect of protocatechuic acid on AST activity in the liver of rats exposed to cadmium. 'Group 2 (Cadmium-induced toxicity) significantly $(p<0.05)$ different from group 1 (normal control). *Group 3 (Cadmium + 10 mg/kg B.W PCA) significantly $(p<0.05)$ different from group 2 (Cadmium-induced toxicity). ${ }^{* *}$ Group 4 $($ Cadmium +20 mg/kg B.W PCA) very significantly $(p<0.05)$ different from group 2 (Cadmium-induced toxicity). "Group $5(10 \mathrm{mg} / \mathrm{kg} \mathrm{B.W}$ PCA) and 6 (20 mg/kg B.W PCA) not significantly ( $p>0.05)$ different from group 1 (normal control)

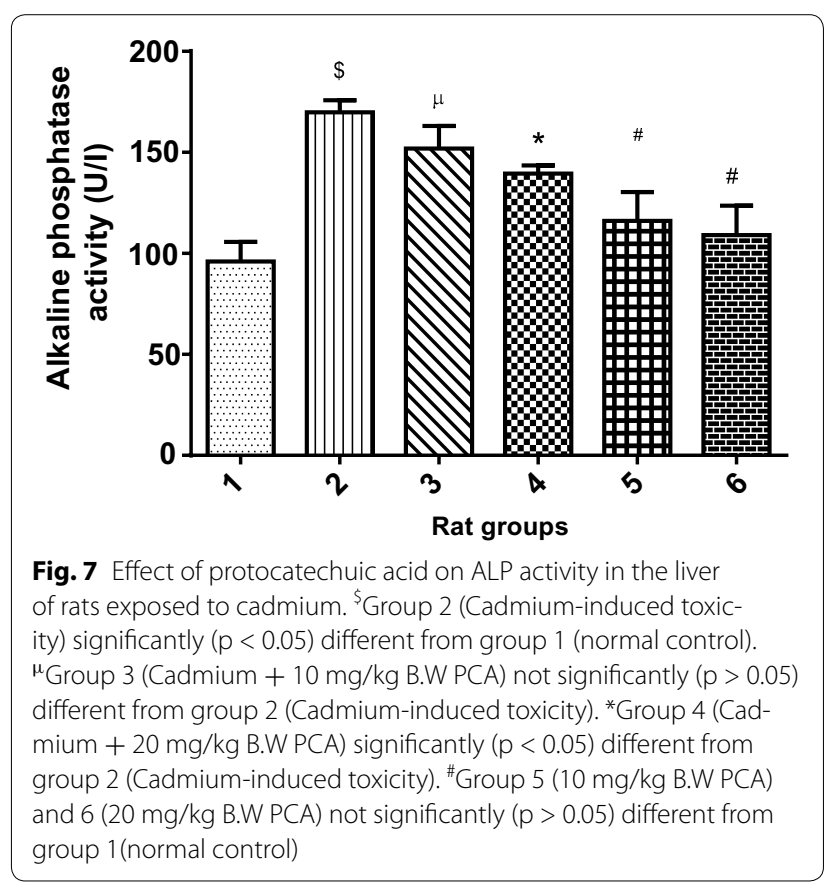

Figures 5, 6 and 7 displayed the effect of PCA on ALT, AST and ALP respectively. The liver enzyme activity in cadmium-induced hepatotoxicity in Wistar rats revealed that there was significant $(\mathrm{p}<0.05)$ increase in ALT, AST and ALP activity of Cd-treated rat group when compared with the normal control group. However, the groups co-treated with cadmium and 10 or $20 \mathrm{mg} / \mathrm{kg}$ PCA significantly $(\mathrm{p}<0.05)$ reduced the liver enzymes activity. Conversely, there was no significant $(p>0.05)$ difference in the enzymes activity following administration of PCA (10 or $20 \mathrm{mg} / \mathrm{kg}$ ) when compared with the normal control group. 


\section{Discussion}

Protocatechuic acid (PCA) has attracted the interest of researchers in the last few years because of the antioxidant activity. However, the possible mechanisms of action of PCA in liver and kidney protection have not been fully investigated. In this study, the significantly $(\mathrm{p}<0.05)$ reduced total protein level in the Cd-treated rat group when compared with the normal control rats may be attributed to the oxidation of protein thereby forming protein-adduct leading to the oxidative damage. However, the significant $(\mathrm{p}<0.05)$ elevation in the total protein level of Cd-treated rat group co-treated with PCA and also the normal rat groups treated with PCA may be as a result of injury on renal and hepatic cells induced by $\mathrm{Cd}$ intoxication which subsequently disturbed protein biosynthesis (Chawla 2003). However, this effect was more profound and effective in the PCA only treated group indicating the potential of PCA to regenerate damaged renal and hepatic tissue, and thus increased protein synthesis in the damaged tissues (Salama and El-Bahr 2007).

The increased levels of serum urea, uric acid and creatinine in the Cd-treated rat group may be attributed to oxidative imbalance in the kidney causing elevated urea, uric acid and creatinine in the blood. Findings from this study correlate with the report given by Gilrolami et al. where urea level was elevated as a result of $\mathrm{Cd}$ induction (Girolami et al. 1989). The significantly $(\mathrm{p}<0.05)$ elevated level of creatinine in Cd-treated rat group when compared with the normal rat group may be attributed to the oxidative damage to the kidney thereby allowing more release of creatinine into the blood. This is in agreement with earlier reports by Renugadevi and Prabu where Cd administration leads to an elevated level of creatinine (Renugadevi and Prabu 2009). This was also linked to the defect in filtration. Also, Shatti reported that rise in creatinine level is an indication of renal-tubular damage due to Cd-induced nephrotoxicity (Shatti 2011). The reduction of the elevated urea, uric acid and creatinine level by cadmium may suggest that PCA exerts nephro-protective effect when exposed to $\mathrm{Cd}$.

ALT and AST are considered to be established indicators of hepatocellular damage (Al-Habori et al. 2002). As a result of antioxidants/oxidants imbalance ratio in the cells, the levels of hepatic enzymes (ALT, AST and ALP) activities may indicate liver tissue damage probably by altered cell membrane permeability leading to the leakage of the enzymes from the tissue to the serum (Gaskill et al. 2005). In this study, a severe hepatic damage was observed by the significant elevation of the hepatic enzymes ALT, AST and ALP activity in the serum of the $\mathrm{Cd}$-induced hepatotoxicity group when compared with the normal control group. Finding from this study is similar to previously reported work by Soufy et al. who reported the hepatotoxic effect of $\mathrm{Cd}$ in rats exposed to the metal (Renugadevi and Prabu 2009). They further affirmed that these changes may be due to direct toxic effects of the toxicant $(\mathrm{Cd})$ on hepatocytes since the liver is the site of detoxification of all types of toxins and chemicals (Renugadevi and Prabu 2009; Soufy et al. 2007). The liver being the organ mostly associated with the detoxification and biotransformation of most foreign compounds that enter the body gets its regulating mechanism impaired as a result of accumulated toxicants which could result to the tissue damage (Camargo and Martinez 2006). This is in agreement with a report by Liu et al. that PCA exerts a potent attenuating effect on fatinduced liver damage (Liu et al. 2010). Similarly, various studies have reported the in vitro antioxidant potential, antibacterial effect and cancer chemopreventive activity of PCA (Li et al. 2011; Chao and Yin 2009; Tanaka et al. 2011) showing its general pharmacological relevance. In this study, accumulation of $\mathrm{Cd}$ in the liver could be deployed to be what accounted for the hepatocellular injury noticed. Interestingly, serum levels of the renal functional markers and hepatic enzymes activities measured in this study were ameliorated upon co-treatment of $\mathrm{Cd}$ and PCA while no adverse effect was noticed following PCA administration in rats suggesting a safe use of this plant based phenolic compound and the dose used in this study on the kidney and the liver.

\section{Conclusion}

From this study, it can be concluded that $\mathrm{Cd}$ induction of lipid peroxidation and elevation of liver marker enzymes and kidney parameters in the serum may interfere with the cellular balance in the kidney and liver thereby causing oxidative damage. However, PCA modulated Cdinduced nephrotoxicity and hepatotoxicity in rats.

\section{Authors' contributions}

SAA and GO participated actively in the design of the experiment and provided mentorship support. SAA supervised the experiment and data analysis while OOS conducted the experiment, carried out data analysis and drafted the article. All authors read and approved the final manuscript.

\section{Competing interests}

The authors declare that they have no competing interests.

Received: 20 April 2015 Accepted: 6 October 2015

Published online: 16 October 2015

\section{References}

Ahn DW, Kim MY, Kim KR, Park PS (1999) Cadmium binding and sodium dependent solute transport in renal brush border membrane vesicles. Toxicol Appl Pharmacol 154:212-218 
Al-Habori M, Al-Aghbari A, Al-Mamary M, Baker M (2002) Toxicological evaluation of Catha edulis leaves. A long term feeding experiment in animals. J Ethnopharmacol 83:209-217

Camargo MM and Martinez CB (2006) Biochemical and physiological biomarkers in Prochilodus lineatus submitted to in situ tests in an urban stream in southern Brazil. Environ Toxicol Pharmacol 21:61-69

Chao CY, Yin MC (2009) Antibacterial effects of roselle calyx extracts and protocatechuic acid in ground beef and apple juice. Foodborne Pathogens Dis 6(2):201-206

Chawla R (2003) Practical clinical biochemistry: methods and interpretations. Jaypee Brothers Publishers, New Delhi

Collin PF, Diehl H (1959) Determination of uric acid. Justus Liebigs Annalen der Chemie 31:1862-1867

DGKC (1972) Recommendations of the Deutsche Gesellschaft fur Klinische Chemie (German Society for Clinical Chemistry). Optimized standard colorimetric method for the determination of alkaline phosphatase. J Clin Chem Biochem 10:182-185

Gaskill CL, Miller LM, Mattoon JS, Hoffmann WE, Burton SA, Gelens HC et al (2005) Liver histopathology and liver and serum alanine aminotransferase and alkaline phosphatase activities in epileptic dogs receiving phenobarbital. Vet Pathol 42:147-160

Girolami JP, Cabos G, Manuel Y (1989) Renal kallikrin excretion as a distal nephrotoxicity marker duing cadmium exposure in rat. J Toxicol 55:117-126

Jarup L, Hellstrom L, Alfven T, Carlsson MD, Grubb A, Persson B (2000) Low level exposure to cadmium and early kidney damage. The OSCAR Study. Occup Environ Med 57:668-672

Li X, Wang X, Chen D, Chen S (2011) Antioxidant activity and mechanism of protocatechuic acid in vitro. Funct Foods Health Dis 7:232-244

Lin CY, Huang CS, Huang CY, Yin MC (2009) Anticoagulatory, antiinflammatory and antioxidative effects of protocatechuic acid in diabetic mice. J Agric Food Chem 57(15):6661-6667

Liu WH, Lin CC, Wang ZH, Mong MC, Yin MC (2010) Effects of protocatechuic acid on trans fat induced hepatic steatosis in mice. J Agric Food Chem 58(18):10247-10252

Lowry OH, Rosebrough NJ, Farr AL, Randal RT (1951) Protein measurement with the folin phenol reagent. J Biol Chem 193:265-275

Morin LG, Prox J (1973) Reduction of ferric phenanthroline: a procedure for determining serum uric acid. Am J Clin Pathol 60(5):691-694

Reitman S, Frankel S (1957) A colorimetric method for the determination of serum glutamic oxalacetic and glutamic pyruvic transaminases. Am J Clin Pathol 28:56-63
Renugadevi J, Prabu SM (2009) Naringenin protects against cadmium-induced oxidative renal dysfunction in rats. Toxicol 256:128-134

Salama AF, El-Bahr SM (2007) Effect of curcumin on cadmium-induced oxidative testicular damage in rats. J Med Res Inst 28:167-173

Satarug S, Moore MR (2004) Adverse health effects of chronic exposure to low-level cadmium in foodstuffs and cigarette smoke. Environ Health Perspect 112:1099-1103

Satarug S, Garrett SH, Sens MA, Sens DA (2010) Cadmium, environmental exposure, and health outcomes. Environ Health Perspect 118:182-190

Searcy RL, Reardon JE, Foreman JA (1967) A new photometric method for serum urea nitrogen determination. Am J Med Technol 33(1):15-20

Shatti AA (2011) Effects of Origanum majorana L. on cadmium induced hepatotoxicity and nephrotoxicity in albino rats. Saudi Med J 32(8):797-805

Soufy HM, Soliman E, El-Manakhly H, Gaafa A (2007) Some biochemical and pathological investigations on monosex Tilapia following chronic exposure to carbofuran pesticides. Global Veterinaria 1:45-52

Spierto FW, MacNeil ML, Burtis CA (1979) The effect of temperature and wavelength on the measurement of creatinine with the Jaffe procedure. Clin Biochem 12(1):18-21

Tanaka T, Tanaka T, Tanaka M (2011) Potential cancer Chemopreventive activity of protocatechuic acid. J Exp Clin Med 3(1):27-33

Tang W, Shaikh ZA (2001) Renal cortical mitochondrial dysfunction upon cadmium metallothionein administration to sprague-dawley rats. J Toxicol Environ Health 63:221-235

Thevenod F (2009) Cadmium and cellular signaling cascades: to be or not to be? Toxicol Appl Pharmacol 238:221-239

Vitaglione P, Donnarumma G, Napolitano A, Galvano F, Gallo A, Scalfi L et al (2007) Protocatechuic acid is the major human metabolite of cyaniding glucosides. J Nutr 137(9):2043-2048

Waisberg M, Joseph P, Hale B, Beyersmann D (2003) Molecular and cellular mechanisms of cadmium carcinogenesis. Toxicol 192:95-117

Zar JH (1984) Biostatistical analysis. Prentice-Hall, New Jersey, ISBN 0-13081542-X 620

\section{Submit your manuscript to a SpringerOpen ${ }^{\circ}$ journal and benefit from:}

- Convenient online submission

Rigorous peer review

- Immediate publication on acceptance

- Open access: articles freely available online

- High visibility within the field

- Retaining the copyright to your article

Submit your next manuscript at $>$ springeropen.com 